\title{
Karakter Morfologi Tanaman Kedelai (Glycine max (L.) Merril) Tercekam Kekeringan Melalui Aplikasi Antioksidan
}

\section{Morphological Character Of Soybean Plant (Glycine max (L.) Merril) Drought Stress Through Antioxidant Application}

\author{
Ahmad Sadam*, Asil Barus, Mariati \\ Program Studi Agroekoteknologi, Fakultas Pertanian, USU, Medan 20155 \\ *Corresponding author : ahmadsadam2893@yahoo.com
}

\begin{abstract}
Decreasing soybean production can not fulfil the needs of soybeans in Indonesia, one of the main causes is the decreasing of agricultural land. To increase soybean production in Indonesia can be reached by expanding the planting area, namely by utilizing the potential land. This research was conducted in plastic house of Faculty of Agriculture, University of Sumatera Utara, Medan with height of place \pm 25 meter above sea level from August 2016 until november 2016, using randomized block design with 2 factors of treatment. the first factor is drought stress with 3 levels ie KL 80\%; KL 60\%; TOS 40\% and the second factor is the provision of antioxidants with 2 kinds of salicylic acid and ascorbic acid. The results showed that the drought stress treatment significantly affected the number of empty pods per plant.
\end{abstract}

Keywords: soybeans, drought stress, antioxidants.

\begin{abstract}
ABSTRAK
Produksi kedelai yang semakin menurun tidak dapat memenuhi kebutuhan kedelai di Indonesia, salah satu penyebabnya utamanya yaitu semakin sempitnya lahan pertanian. Untuk meningkatkan produksi kedelai di Indonesia dapat ditempuh dengan cara perluasan areal tanam, yaitu dengan memanfaatkan tanah yang berpotensi. Penelitian ini dilaksanakan di rumah plastik Fakultas Pertanian Universitas Sumatera Utara, Medan dengan ketinggian tempat \pm 25 meter di atas permukaan laut dari bulan agustus 2016 sampai november 2016, menggunakan rancangan acak kelompok dengan 2 faktor perlakuan . faktor pertama adalah cekaman kekeringan dengan 3 taraf yaitu KL 80\%; KL 60\%; KL 40\% dan faktor kedua adalah pemberian antioksidan dengan 2 macam yaitu asam salisilat dan asam askorbat. Hasil penelitian menunjukkan bahwa perlakuan cekaman kekeringan berpengaruh nyata terhadap jumlah polong hampa per tanaman.
\end{abstract}

Kata Kunci : kedelai, cekaman kekeringan, antioksidan.

\section{PENDAHULUAN}

Kedelai merupakan salah satu komoditas tanaman pangan bernilai ekonomis penting, karena perannya sebagai pemenuhan kebutuhan gizi terjangkau masyarakat luas.Selain itu, kedelai juga merupakan sumber protein nabati dengan kandungan $39 \%$, dimana $2 \%$ dari seluruh rakyat Indonesia memperoleh sumber protein dari kedelai. Dilihat dari segi pangan dan gizi, kedelai merupakan sumber protein yang paling murah di dunia. Kedelai sebagai bahan baku makanan yang banyak dikonsumsi rakyat Indonesia yaitu tempe dan tahu (Ramadhani, 2009).

Sampai saat ini pemenuhan kebutuhan kedelai masih dilakukan impor dari berbagai negara. Untuk membatasi impor kedelai atau ketergantungan pada negara lain, perlu 
dilakukan perluasan areal tanam. Namun demikian, perluasan areal tanam kearah lahan optimal sulit dilakukan karena beberapa hal seperti persaingan dengan komoditas tanaman palawija lainnya yang lebih kompetitif dan alih fungsi lahan, di mana areal pertanian bahkan beralih fungsi menjadi areal non pertanian. Di sisi lain masih banyak tanah di Indonesia belum dimanfaatkan akibat keterbatasan teknik budidaya, salah satunya adalah lahan kering (Namdeo, 2007).

Lahan kering adalah hamparan lahan yang tidak pernah digenangi atau tergenang air pada sebagian besar waktu dalam setahun (Adimiharja et al., 2000). lahan kering merupakan salah satu sumberdaya yang mempunyai potensi besar untuk pembangunan pertanian, baik tanaman pangan, hortikultura, perkebunan, dan peternakan. pengembangan pertanian di lahan kering untuk tanaman pangan perlu didorong dengan berbagai inovasi teknologi. Mengingat potensinya yang besar sehingga cukup potensial untuk mendukung usaha pemantapan ketahanan pangan di Indonesia dan merupakan pilihan stategis dalam menghadapi tantangan penigkatan produksi pangan untuk mendukung program ketahanan pangan nasional (Wahyunto dan Rizatus, 2006).

Senyawa antioksidan dalam pengertian kimia berarti senyawa pemberi elektron. Secara biologi, pengertian antioksidan adalah senyawa yang mampu menangkal atau meredam dampak negatif oksidan dalam tubuh. Antioksidan bekerja dengan cara menyumbangkan satu atau lebih elektron kepada radikal bebas, sehingga radikal bebas tersebut dapat diredam. Kemampuanantioksidanuntukmenginduksitol eransicekamanterhadapcekamanabiotiktergant ungdarijenistanaman, tahapperkembangan, metodeaplikasidankonsentrasiantioksidan.Upa yapeningkatankandunganantioksidandapatdila kukandenganaplikasiantioksidanesksogenous.

Beberapajenisantioksidan yang dapatdigunakanadalahasamaskorbat, asamsalisilat, kitosan dan $\alpha$ tokoferol(Ardiansyah, 2013).
Berdasarkan latar belakang yang telah dipaparkan maka perlu dilakukan peningkatan produksi tanaman kedelai di Indonesia dengan memanfaatkan antioksidan sebagai salah satu bentuk intensifikasi. Untuk itu dapat dilakukan penelitian mengenai peran antioksidan dalam mengatasi cekaman kekeringan pada tanaman kedelai.

\section{BAHAN DAN METODE}

Penelitian ini dilaksanakan di Rumah Kassa Fakultas Pertanian Universitas Sumatera Utara, Medan dengan ketinggian tempat \pm 32 meter di atas permukaan laut, mulai bulan September 2016 sampai November 2016.

Bahan

digunakanialahbenihkedelaisebagaiobjek

yang diamati, antioksidan (alphatokoferol dan kitosan) sebagaiperlakuan yang akandiaplikasikanpadatanamankedelai,

polybaguntukwadah media tanam, plastik sebagai naungan,air untukmenyiramtanamandanbahan-bahan lain yang mendukungpenelitianini.

Alat yang digunakanyaitucangkuluntukmembersihkangu lmapadarumahplastik, pisau/cutteruntukmemotong-motongplastik, label sebagaipenanda,meteranuntukmengukur, sprayer untukmengaplikasikanantioksidan, timbangananalitikuntukmenimbangbobot yang akanditimbang,gemboruntukmenyiram, serta alat pendukunglainnya.

Penelitian menggunakan rancangan acak kelompok (RAK) dengan faktor :

Faktor I : Cekaman Kekeringan (K) dengan 3 taraf, yaitu ; K1 :80 \% KL, K2 :60 \% KL, K3 $: 40 \%$ KL. Faktor II : Pemberian Antioksidan (A) dengan 3 taraf, yaitu ; $A_{0}$ : Tanpa Antioksidan (Kontrol), $A_{1}$ : Alpha Tokoferol (500 ppm), $A_{2}$ : Kitosan (500 ppm)

Data hasil penelitian dianalisis dengan menggunakan sidik ragam denganmodel linear. Jika dari hasil analisis sidik ragam perlakuan menunjukkan pengaruh yang nyata, maka dilanjutkan dengan Uji Beda Rataan 
berdasarkan Duncan Multiple RangeTest (DMRT) pada taraf 5\% (Steel and Torrie, 1989). Data dianalisis dengan menggunakan Microsoft Exel 2007.

\section{HASIL DAN PEMBAHASAN}

Hasil

Dari hasil analisis sidik ragam diketahui bahwa cekaman kekeringan dan pemberian antioksidan berpengaruh tidak nyata terhadap semua peubah amatan. Interaksi antara pengaruh cekaman kekeringan dan pemberian antioksidan berpengaruh nyata terhadap peubah amatan tinggi tanaman pada 4 MST dan bobot kering biji.

Tabel 1. Tinggi tanaman kedelaidengan perlakuan cekaman kekeringan dan pemberian antioksidan.

\begin{tabular}{|c|c|c|c|c|c|}
\hline \multirow{2}{*}{ (MST) } & \multirow{2}{*}{ Antioksidan } & \multicolumn{3}{|c|}{ Cekaman Kekeringan (\%KL) } & \multirow{2}{*}{ Rataan } \\
\hline & & K1 (80) & K2 (60) & K3 (40) & \\
\hline \multirow{5}{*}{2} & & & & ............ & \\
\hline & A0 (Kontrol) & 20.63 & 19.21 & 20.00 & 19.94 \\
\hline & A1 (Alpha Tokoferol) & 19.78 & 19.67 & 20.57 & 20.00 \\
\hline & A2 (Kitosan) & 19.63 & 20.88 & 21.00 & 20.50 \\
\hline & Rataan & 20.01 & 19.92 & 20.52 & \\
\hline \multirow{4}{*}{4} & A0 (Kontrol) & $46.76 \mathrm{ab}$ & $42.57 \mathrm{~b}$ & $44.63 \mathrm{ab}$ & 44.65 \\
\hline & A1 (Alpha Tokoferol) & $48.51 \mathrm{ab}$ & 45.53ab & 49.10ab & 47.71 \\
\hline & A2 (Kitosan) & $40.40 \mathrm{~b}$ & $53.21 \mathrm{a}$ & $46.79 \mathrm{ab}$ & 46.80 \\
\hline & Rataan & 45.22 & 47.10 & 46.84 & \\
\hline \multirow{3}{*}{6} & A0 (Kontrol) & 103.18 & 100.09 & 96.25 & 99.84 \\
\hline & A1 (Alpha Tokoferol) & 102.53 & 99.80 & 101.37 & 101.23 \\
\hline & A2 (Kitosan) & 89.09 & 110.25 & 96.29 & 98.54 \\
\hline \multirow{5}{*}{8} & Rataan & 98.27 & 103.38 & 97.97 & \\
\hline & A0 (Kontrol) & 140.46 & 135.39 & 135.35 & 137.07 \\
\hline & A1 (Alpha Tokoferol) & 135.29 & 131.03 & 133.87 & 133.39 \\
\hline & A2 (Kitosan) & 121.47 & 143.53 & 132.99 & 132.66 \\
\hline & Rataan & 132.41 & 136.65 & 134.07 & \\
\hline
\end{tabular}

Keterangan: Angka yang diikuti notasi huruf yang berbeda pada kelompok baris yang sama adalah berbeda nyata berdasarkan Uji Jarak Berganda Duncan pada taraf 5\%.

Dari Tabel 1 pada perlakuan cekaman kekeringan rataan tertinggi pada 8 MST perlakuan cekaman kekeringan $60 \% \mathrm{KL}$ sebesar136.65 $\mathrm{cm}$ dan terendah pada $2 \mathrm{MST}$ perlakuan cekaman kekeringan $60 \% \mathrm{KL}$ sebesar19.92 cm. Pada perlakuan antioksidan rataan tertinggi pada 5 MST perlakuan kontrol(A0) sebesar137.07 $\mathrm{cm}$ dan terendah pada 2MST perlakuan kontrol (A0)sebesar19.94 cm. Interaksi antara perlakuan $60 \% \mathrm{KL}$ dan kitosan (A2) pada 8 MST menghasilkan tanaman tertinggi sebesar $143.53 \mathrm{~cm}$ dan pada perlakuan $60 \%$ KL dan interaksi antara perlakuan $60 \% \mathrm{KL}$ dan kontrol (A0) pada 2 MST sebesar $19.21 \mathrm{~cm}$.

Tabel 2. Jumlah daun dan diameter batang kedelai dengan perlakuan cekaman kekeringan dan pemberian antioksidan.

\begin{tabular}{|c|c|c|c|c|}
\hline \multirow{2}{*}{ Antioksidan } & \multicolumn{3}{|c|}{ Cekaman Kekeringan (\%KL) } & \multirow[t]{2}{*}{ Rataan helai / mm } \\
\hline & K1 (80) & $\mathrm{K} 2(60)$ & K3 (40) & \\
\hline & & & elai / mm...... & \\
\hline A0 (Kontrol) & $20.42 / 2.08$ & $19.67 / 2.05$ & $19.42 / 2.05$ & $19.83 / 2.06$ \\
\hline A1 (Alpha Tokoferol ) & $19.42 / 2.07$ & $20.58 / 2.67$ & $18.92 / 2.07$ & $19.64 / 2.27$ \\
\hline A2 (Kitosan) & $18.25 / 2.05$ & $20.08 / 2.05$ & $20.00 / 2.02$ & $19.44 / 2.04$ \\
\hline Rataan & $19.36 / 2.07$ & $20.11 / 2.26$ & $19.44 / 2.05$ & \\
\hline
\end{tabular}


Dari Tabel 2 diketahui bahwa cekaman kekeringan $60 \%$ KL menghasilkan jumlah daun trifoliate tertinggi sebesar 20.11helai dan terendah pada perlakuan $80 \%$ KL sebesar 19.36 helai.Sedangkan pemberian antioksidan kontrol (A0)menghasilkan jumlah daun trifoliate tertinggi sebesar 19.83 helai dan terendah pada perlakuan kitosan (A2) sebesar 19.44 helai.Interaksi antara kombinasi perlakuan $60 \% \mathrm{KL}$ dan alpha tokoferol(A1) menghasilkan jumlah daun trifoliate tertinggi sebesar 30.88helai dibandingkan kombinasi perlakuan $80 \%$ KL dan kitosan menghasilkan jumlah daun trifoliate terendah sebesar 18.25helai.
PadaTabel 2 diketahui bahwa perlakuan cekaman kekeringan 60\% KL menghasilkan diameter batang dengan rataan tertinggi sebesar $2.26 \mathrm{~mm}$ dan terendah pada perlakuan $40 \% \quad \mathrm{KL}$ sebesar $2.05 \mathrm{~mm}$. Sedangkan pemberian antioksidan alpha tokoferol (A1) menghasilkan diameter batang dengan rataan tertinggi sebesar 2.27 mmdan terendah pada pemberian antioksidan kitosan (A2) sebesar $2.04 \mathrm{~mm}$. Interaksi antara perlakuan $60 \%$ KL dan pemberian antioksidan alpha tokoferol (A1) menghasilkan diameter batang dengan rataan tertinggi sebesar $2.67 \mathrm{mmdan}$ terendah pada kombinasi 40\% KL dan kitosan (A2) sebesar $2.05 \mathrm{~mm}$.

Tabel 3. Jumlah cabang produktif dan total luas daun kedelai dengan perlakuan cekaman kekeringan dan pemberian antioksidan.

\begin{tabular}{|c|c|c|c|c|}
\hline \multirow{2}{*}{ Antioksidan } & \multicolumn{3}{|c|}{ Cekaman Kekeringan (\%KL) } & \multirow{2}{*}{$\begin{array}{c}\text { Rataan cabang / } \\
\mathrm{cm}^{2}\end{array}$} \\
\hline & K1 (80) & $\mathrm{K} 2(60)$ & K3 (40) & \\
\hline & & & bang $/ \mathrm{cm}^{2}$. & \\
\hline A0 (Kontrol) & $3.08 / 37.16$ & $2.75 / 48.05$ & $3.33 / 45.51$ & $3.06 / 43.57$ \\
\hline A1 (Alpha Tokoferol ) & $3.08 / 43.75$ & $3.50 / 39.66$ & $3.00 / 37.55$ & $3.19 / 40.32$ \\
\hline A2 (Kitosan) & $3.17 / 43.77$ & $2.92 / 50.98$ & $3.33 / 47.56$ & $3.14 / 47.44$ \\
\hline Rataan & $3.11 / 41.56$ & $3.06 / 46.23$ & $3.22 / 43.54$ & \\
\hline
\end{tabular}

Pada Tabel 3 diketahui bahwa perlakuan cekaman kekeringan $40 \% \mathrm{KL}$ menghasilkan jumlah cabang produktif dengan rataan tertinggi sebesar 3.22 cabang dan terendah pada perlakuan $60 \%$ KL sebesar 3.06 cabang. Sedangkan pemberian antioksidan alpha tokoferol (A1) menghasilkan jumlah cabang produktif dengan rataan tertinggi sebesar 3.19cabangdan terendah pada pemberian antioksidan tanpa perlakuan (kontrol)(A0) sebesar3.06 cabang. Interaksi antara perlakuan $60 \% \mathrm{KL}$ dan pemberian antioksidan alpha tokoferol (A1) menghasilkan jumlah cabang produktif dengan rataan tertinggi sebesar 3.50 cabang dan terendah pada kombinasi perlakuan $60 \%$ KL dankontrol (A0) sebesar 2.75cabang.

Pada Tabel 3 diketahui bahwa perlakuan cekaman kekeringan 60\% KL menghasilkan total luas daun dengan rataan tertinggi sebesar $46.23 \mathrm{~cm}^{2}$ dan terendah pada perlakuan $80 \% \mathrm{KL}$ sebesar $41.56 \mathrm{~cm}^{2}$. Sedangkan pemberian antioksidan kitosan (A2) menghasilkan total luas daun dengan rataan tertinggi sebesar $47.44 \mathrm{~cm}^{2}$ dan terendah pada pemberian antioksidanalpha tokoferol (A1) sebesar $40.32 \mathrm{~cm}^{2}$.Interaksi antara perlakuan $60 \% \mathrm{KL}$ dan pemberian antioksidan kitosan (A2) menghasilkan total luas daun dengan rataan tertinggi sebesar $50.98 \mathrm{~cm}^{2}$ dan terendah pada kombinasi $80 \%$ KL dan tanpa antioksidan (A0) sebesar 37.16 $\mathrm{cm}^{2}$.

PadaTabel 4 diketahui bahwa perlakuan cekaman kekeringan 80\% KL menghasilkan bobot kering tajuk dengan rataan tertinggi sebesar 3.69gdan terendah pada perlakuan $40 \% \mathrm{KL}$ sebesar $3.46 \mathrm{~g}$. Sedangkan pemberian antioksidan alpha tokoferol (A1) menghasilkan bobot kering tajuk dengan rataan tertinggi sebesar 3.76gdan 
terendah pada pemberian antioksidankitosan (A2) sebesar 3.42g.Interaksi antara perlakuan $80 \%$ KL dan pemberian antioksidan alpha tokoferol (A1) menghasilkan bobot kering tajuk dengan rataan tertinggi sebesar 4.16 gdan terendah pada kombinasi $40 \%$ KL dan

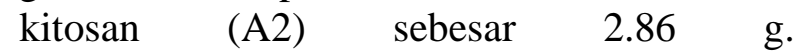

Tabel 4. Bobot Kering Tajuk Kedelai kedelai dengan perlakuan cekaman kekeringan dan pemberian antioksidan.

\begin{tabular}{|c|c|c|c|c|}
\hline \multirow{2}{*}{ Antioksidan } & \multicolumn{3}{|c|}{ Cekaman Kekeringan (\% KL) } & \multirow{2}{*}{ Rataan g/ cm } \\
\hline & K1 (80) & $\mathrm{K} 2(60)$ & K3 (40) & \\
\hline & & & $\ldots \mathrm{g} / \mathrm{cm} \ldots .$. & \\
\hline A0 (Kontrol) & $3.15 / 3.65$ & $3.88 / 3.28$ & $3.84 / 3.42$ & $3.62 / 3.45$ \\
\hline A1 (Alpha Tokoferol ) & $4.16 / 3.64$ & $3.39 / 3.36$ & $3.74 / 3.27$ & $3.76 / 3.42$ \\
\hline A2 (Kitosan) & $3.77 / 3.72$ & $3.64 / 3.16$ & $2.86 / 3.61$ & $3.42 / 3.49$ \\
\hline Rataan & $3.69 / 3.67$ & $3.64 / 3.27$ & $3.48 / 3.43$ & \\
\hline
\end{tabular}

Pada Tabel 4 diketahui bahwa perlakuan cekaman kekeringan $80 \% \mathrm{KL}$ menghasilkan rasio tajuk akar dengan rataan tertinggi sebesar $3.67 \mathrm{~g}$ dan terendah pada perlakuan $60 \%$ KL sebesar $3.27 \mathrm{~g}$. Sedangkan pemberian antioksidan kitosanl (A2) menghasilkan rasio tajuk akar dengan rataan tertinggi sebesar $3.49 \mathrm{~g}$ dan terendah pada pemberian antioksidan alpha tokoferol (A1) sebesar 3.42g.Interaksi antara perlakuan $80 \%$ KL dan kitosan (A2) menghasilkan rasio tajuk akar dengan rataan tertinggi sebesar $3.72 \mathrm{~g}$ dan terendah pada kombinasi $60 \% \mathrm{KL}$ dan kitosan (A2) sebesar $3.16 \quad \mathrm{~g}$

Tabel 5. Bobot Kering Akar dan umur berbunga kedelai dengan perlakuan cekaman kekeringan dan pemberian antioksidan.

\begin{tabular}{|c|c|c|c|c|}
\hline \multirow{2}{*}{ Antioksidan } & \multicolumn{3}{|c|}{ Cekaman Kekeringan (\%KL) } & \multirow{2}{*}{ Rataan g / hari } \\
\hline & $\mathrm{K} 1(80)$ & $\mathrm{K} 2(60)$ & K3 (40) & \\
\hline & \multicolumn{4}{|c|}{ 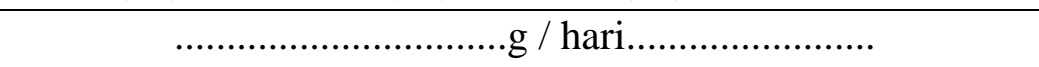 } \\
\hline A0 (Kontrol) & $1.20 / 38.67$ & $1.43 / 39.00$ & $1.32 / 38.33$ & $1.32 / 38.67$ \\
\hline A1 (Alpha Tokoferol) & $1.35 / 39.00$ & $1.24 / 38.67$ & $1.35 / 38.33$ & $1.31 / 38.67$ \\
\hline A2 (Kitosan) & $1.24 / 39.00$ & $1.37 / 38.67$ & $1.08 / 38.67$ & $1.23 / 38.78$ \\
\hline Rataan & $1.26 / 38.89$ & $1.34 / 38.78$ & $1.25 / 38.44$ & \\
\hline
\end{tabular}

Pada Tabel 5 diketahui bahwa perlakuan cekaman kekeringan $60 \% \mathrm{KL}$ menghasilkan bobot kering akar dengan rataan tertinggi sebesar 1.34 gdan terendah pada perlakuan $40 \%$ KL sebesar $1.25 \mathrm{~g}$. Sedangkan pemberian antioksidan tanpa perlakuan (kontrol) (A0) menghasilkan bobot kering akar dengan rataan tertinggi sebesar 1.32gdan terendah pada pemberian antioksidankitosan (A2) sebesar 1.23g.Interaksi antara perlakuan $60 \% \mathrm{KL}$ dan kontrol (A0) menghasilkan bobot kering akar dengan rataan tertinggi sebesar $1.43 \mathrm{~g}$ dan terendah pada kombinasi $40 \%$ KL dan kitosan (A2) sebesar $1.08 \mathrm{~g}$.

Dari Tabel 5 diketahui bahwa perlakuan cekaman kekeringan $80 \%$ KL menghasilkan umur berbunga dengan rataan tercepat sebesar 38.89 haridan terendah pada perlakuan $40 \%$ KL sebesar 38.44 hari. Sedangkan pemberian antioksidan kitosan (A2) menghasilkan umur berbunga dengan rataan tercepat sebesar 38.78haridan terlambat pada pemberian antioksidantanpa antioksidan (A0) dan alpha tokoferol sebesar 38.67 hari. Interaksi antara $80 \% \mathrm{KL}$ dan alfatokoferol (A1), $80 \%$ KL dan alfatokoferol (A2), 60\% 
KL dan (A0) menghasilkan umur berbunga dengan rataan tercepat sebesar 39.00 hari dan terlambat pada perlakuan $40 \%$ KL kontrol (A0) dan $40 \% \mathrm{KL}$ alfatokoferol (A1) sebesar 38.33 hari.

Pada Tabel 6 bahwa perlakuan cekaman kekeringan $80 \%$ KL menghasilkan jumlah polong berisi per tanaman dengan rataan tertinggi sebesar 122.11 polongdan terendah pada perlakuan $40 \%$ KL sebesar 118.22 polong. Sedangkan pemberian antioksidan kitosan (A2) menghasilkan jumlah polong berisi per tanaman dengan rataan tertinggi sebesar 122.44 polongdan terendah pada pemberian antioksidantanpa perlakuan (kontrol)(A0) sebesar 116.56 polong.Interaksi antara perlakuan $40 \% \mathrm{KL}$ dan alpha tokoferol (A1) menghasilkan jumlah polong berisi per tanaman dengan rataan tertinggi sebesar 128.33 polong dan terendah pada kombinasi $40 \%$ KL dan tanpa perlakuan (kontrol) (A0) sebesar 112.00 polong.

Tabel 6. Jumlah polong berisi per tanamandan Bobot kering biji per tanaman kedelai dengan perlakuan cekaman kekeringan dan pemberian antioksidan.

\begin{tabular}{|c|c|c|c|c|}
\hline \multirow{2}{*}{ Antioksidan } & \multicolumn{3}{|c|}{ Cekaman Kekeringan (\% KL) } & \multirow{2}{*}{ Rataan polong / g } \\
\hline & K1 (80) & $\mathrm{K} 2(60)$ & K3 (40) & \\
\hline & \multicolumn{4}{|c|}{ 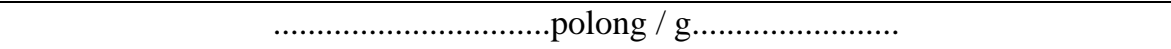 } \\
\hline A0 (Kontrol) & $123.67 / 6.55 \mathrm{ab}$ & $114.00 / 5.93 b$ & $112.00 / 5.45 b$ & $116.56 / 5.98$ \\
\hline A1 (Alpha Tokoferol ) & $117.33 / 5.79 b$ & $121.00 / 5.81 b$ & $128.33 / 8.02 \mathrm{a}$ & $122.22 / 6.54$ \\
\hline A2 (Kitosan) & $125.33 / 5.72 b$ & $127.67 / 6.28 \mathrm{ab}$ & 114.33 / 6.36ab & $122.44 / 6.12$ \\
\hline Rataan & $122.11 / 6.02$ & 120.89 & $118.22 / 6.61$ & \\
\hline
\end{tabular}

Keterangan : Angka yang diikuti notasi huruf yang berbeda pada kelompok baris yang sama adalah berbeda nyata berdasarkan Uji Jarak Berganda Duncan pada taraf 5\%

Pada Tabel 6 diketahui bahwa interaksi antara perlakuan $40 \% \mathrm{KL}$ dan alpha tokoferol (A1) menghasilkan rataan bobot kering biji per tanaman tertinggi sebesar 8.02 gberbeda tidak nyata dengan perlakuan $80 \%$
KL dan kontrol (A0), 60\% KL dan kitosan (A2), $40 \% \mathrm{KL}$ dan kitosan (A2). Interaksi perlakuan $40 \% \mathrm{KL}$ dan tanpa perlakuan (kontrol) (A0) menghasilkan rataan bobot kering biji terendah sebesar $5.45 \mathrm{~g}$.

Tabel 7. Jumlah polong hampa per tanaman dan bobot 100 biji keringkedelai dengan perlakuan cekaman kekeringan dan pemberian antioksidan.

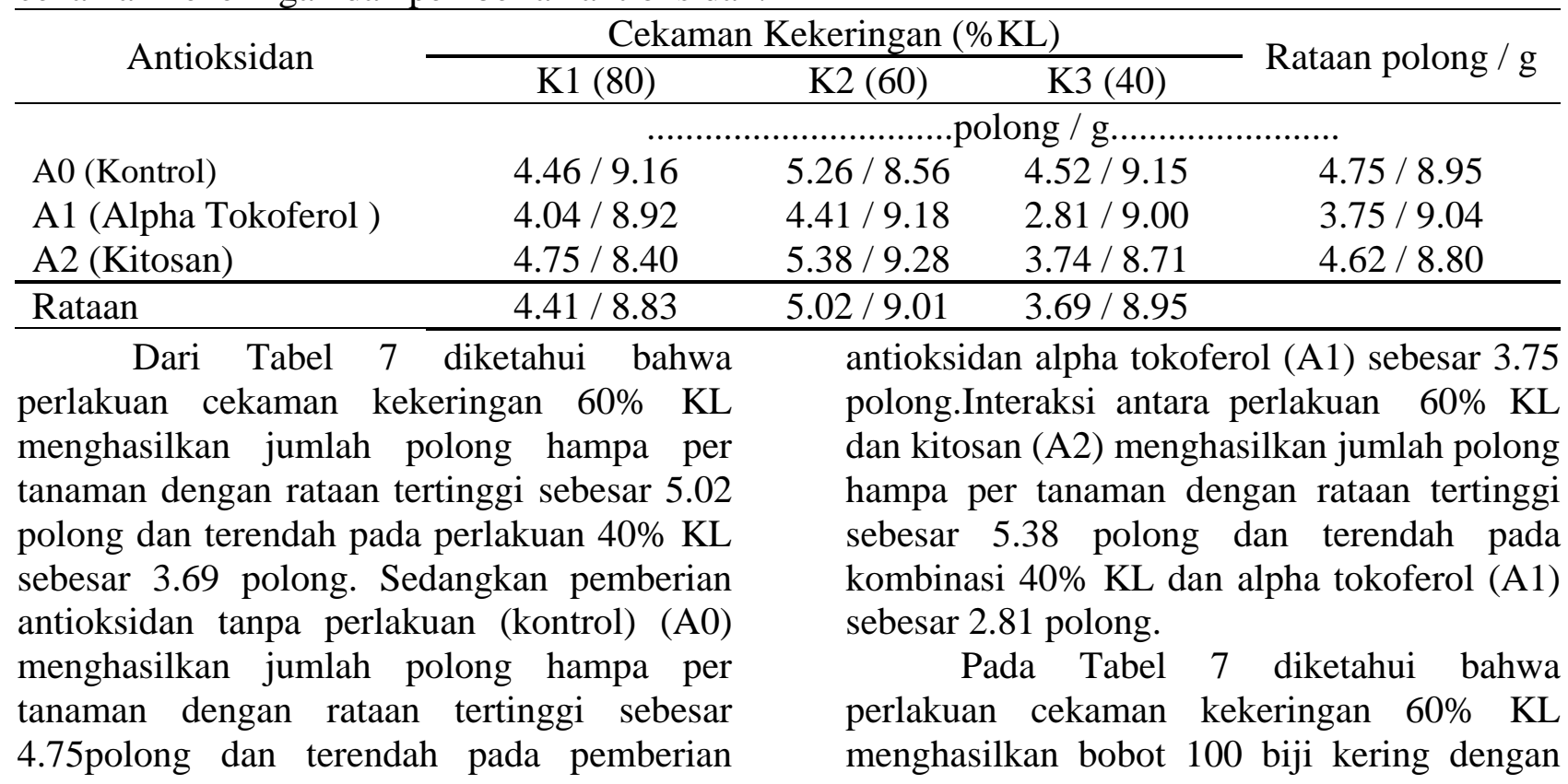


rataan tertinggi sebesar $9.01 \mathrm{~g}$ dan terendah pada perlakuan $80 \%$ KL sebesar $8.83 \mathrm{~g}$. Sedangkan pemberian antioksidan alpha tokoferol (A1) menghasilkan bobot 100 biji kering dengan rataan tertinggi sebesar $9.04 \mathrm{~g}$ dan terendah pada pemberian antioksidan kitosan (A2)sebesar 8.80 g.Interaksi antara perlakuan $60 \%$ KL dan kitosan (A2) menghasilkan bobot 100 biji kering dengan rataan tertinggi sebesar $9.28 \mathrm{~g}$ dan terendah pada kombinasi $80 \%$ KL dan kitosan (A2) sebesar $8.40 \mathrm{~g}$.

Berdasarkan hasil analisis statistik diketahui bahwa perlakuan cekaman kekeringan berpengaruh tidak nyata terhadap parameter tinggi tanaman, jumlah daun, diameter batang, jumlah cabang, total luas daun, bobot kering tajuk, bobot kering akar, rasio tajuk akar, umur berbunga, jumlah polong berisi per tanaman, jumlah polong hampa, berat kering biji per tanaman, dan bobot kering 100 biji.

Pengisian biji kedelai berlangsung selama fase akhir pematangan biji. Fase tersebut sangat dipengaruhi oleh ketersediaan air (Kim and Cgung. 2007 ; Dhaubhadel et al. 2007). Hal ini menjelaskan bahwa bobot kering biji per tanaman dan bobot kering biji per tanaman meningkat seiring dengan peningkatan \%KL. Oleh karena itu. semakin rendah ketersediaan air pada fase pengisian polong akan mengakibatkan semakin rendahnya jumlah polong yang juga mengakibatkan penurunan bobot kering biji per tanaman dan bobot 100 biji kering. Hasil analisis bobot 100 biji (g) menunjukkan bahwa perlakuan $\mathrm{K} 2(60 \% \mathrm{KL})$ menghasilkan rataan tertinggi yakni $13.51 \mathrm{~g}$. Ukuran biji yang dihasilkan ditentukan secara genetik. namun faktor lingkungan selama fase pengisian biji juga berpengaruh. Salah satu faktor lingkungan yang merugikan adalah cekaman kekeringan. Hal ini didukung oleh pernyataan Mursito (2003) bahwa ukuran biji suatu varietas ditentukan secara genetik. namun ukuran biji yang terbentuk juga ditentukan oleh lingkungan semasa pengisian biji. Penurunan hasil ini karena lamanya tanaman mencapai fase kritis setelah diberi perlakuan cekaman kekeringan. Hal ini sesuai dengan literatur Hendriyani dan Setiari (2009) yang menyatakan bahwa cekaman air pada masa generatif, misalnya pada saat pengisian polong, akan menurunkan produksi. Cekaman kekeringan yang terjadi pada saat pertumbuhan generatif, misalnya saat pengisian polong, akan menurunkan produksi.

Berdasarkan hasil analisis statistik diketahui bahwa pemberian antioksidan berpengaruh tidak nyata terhadap parameter tinggi tanaman, jumlah daun, diameter batang, jumlah cabang, total luas daun, bobot kering tajuk, bobot kering akar, rasio tajuk akar, umur berbunga, jumlah polong berisi per tanaman,jumlah polong hampa per tanaman, berat kering biji per tanaman, dan bobot kering 100 biji. Alpha-tokoferol (Vitamin E) memainkan peran unik sebagai antioksidan dan stabilisasi bagi biologis membran. Hal ini disintesis di kloroplas dan proplastids dan berlokasi di membran sel, terutama pada membran tilakoid pada kloroplas. Struktur dan lokasi dari alpha-tokoferol menentukan fungsinya sebagai stabilisasi membran (Hess. 1993; Smirnoff. 1996). Hal ini diduga karena tanaman dapat melakukan fotosintesis dengan lebih baik sehingga dapat membentuk dan mengisi polong. Hal ini menunjukkan bahwa pemberian tanpa antioksidan mampu meningkatkan produksi tanaman kedelai. sedangkan pemberian antioksidan asam askorbat menurunkan produksi tanaman. Hal ini sejalan dengan peningkatan jumlah polong berisi pertanaman dan bobot biji per tanaman yang mendapat perlakuan yang sama. Ukuran biji yang dihasilkan ditentukan secara genetik. namun faktor lingkungan selama fase pengisian biji juga berpengaruh.

Di antara kedua jenis antioksidan yang diberikan yaitu alfa tokoferol danKitosan diperoleh antioksidan terbaik adalah alfa tokoferoldalam mengatasi cekaman kekeringan pada tanaman kedelai. Hal ini sesuai dengan pernyataan Arora et al., (2002) bahwa mekanisme alfa tokoferolterhadap cekaman berpengaruh pada metabolisme sel tanaman dengan melakukan perlindungan 
terhadap oksigen reaktif yang diproduksi berlebih ketika terjadi cekaman.

Berdasarkan hasil analisis statistik diketahui bahwa Interaksi antara pengaruh cekaman kekeringan dan pemberian antioksidan berpengaruhnyata terhadaptinggi tanaman pada 4 MST dan berat kering biji per tanaman.

Interaksi antara perlakuan cekaman kekeringan dan pemberian antioksidan berpengaruh nyata terhadap tinggi tanaman dengan data tertinggi pada perlakuan cekaman kekeringan $40 \%$ dan pemberian kitosan K3A2 yaitu $53.2 \mathrm{~cm}$ dan terendah K2A0 yaitu 42.57 cm umur 4 MST pada fase vegetatif tanaman. Fase fegetatif tanaman merupakan fase perkembangan dan pembelahan sel-sel secara aktif sehingga rentan terhadap kekurangan air. Menurut Purwanto dan Agustono (2010) bahwa kondisi cekaman kekeringan pada fase vegetatif dapat menurunkan tinggi tanaman.

Cekaman kekeringan menghambat pertumbuhan tanaman, menyebabkan tanaman menjadi kerdil. Tinggi tanaman menurun dengan meningkatnya cekaman kekeringan, terhambatnya pertumbuhan tanaman disebabkan karena terganggunya proses fotosintesis akibat kekurangan air karena berhubungan dengan turgor dan hilangnya turgiditas dapat menghentikan pembelahan dan pembesaran sel yang mengakibatkan tanaman lebih kecil (Sharifa dan Muriefah, 2015). Dijelaskan dalam Lestario et al. (2008) radikal bebas yang disebabkan oleh lingkungan yang terckam adalah senyawa kimia yang mempunyai satu atau lebih elekton yang tidak berpasangan. Senyawa ini bersifat tidak stabil dan sangat reaktif. Senyawa ini harus mencari elektron lain sebagai pasangan untuk mencapai kestabilan, peran antioksidan kitosan yaitu menjadi pasangan elektron dari radikal bebas untuk menetralisirnya.

Bobot kering biji per tanaman yang tertinggi diperoleh pada cekaman kekeringan $40 \%$ dan pemberian alpha tokoferol K3A1 yaitu $8.02 \mathrm{~g}$ dan terendah K3A0 yaitu $5.45 \mathrm{~g}$. Pada tanaman kedelai, fase pengisian polong (R5 dan R6) merupakan fase yang sangat peka terhadap ketersediaan air. Perkembangan biji pada R5 dikarakterisasi dengan cepatnya peningkatan bobot biji dan akumulasi nutrisi berlangsung hingga R6 yang merupakan fase pengisian polong tetapi masih belum matang. Pengisian biji kedelai berlangsung selama fase akhir pematangan biji. Fase tersebut sangat dipengaruhi oleh ketersediaan air (Kim and Cgung, 2007 ; Dhaubhadel et al, 2007). Hal ini menjelaskan bahwa bobot kering biji per tanaman meningkat seiring dengan peningkatan \%KL. Oleh karena itu, semakin rendah ketersediaan air pada fase pengisian polong akan mengakibatkan semakin rendahnya jumlah polong berisi yang juga mengakibatkan penurunan bobot kering biji per tanaman dan bobot 100 biji kering. Menurut Hamayun et al. (2010) bahwa penurunan hasil panen dengan meningkatnya cekaman kekeringan pada masa pembungaan dan tahap pengisian biji mengakibakan penurunan jumlah polong karena keguguran bunga pada masa pembungaan sehingga mempengaruhi jumlah biji per polong. Frederick et al. (2001)menyatakan bahwa penurunan proses fotosintesis merupakan faktor utama yang membatasi hasil dan semua komponen hasil. Proses fotosintesis yang terganggu berakibat menurunnya hasil dan semua komponen hasil. Proses fotosintesis yang terganggu berakibat menurunnya hasil biji, dan komponen hasil lainnya. Bila tanaman mengalami cekaman kekeringan selama fase pengisian biji, sedangkan fotosintesis tidak dapat mencukupi kebutuhan dari sink maka tanaman akan menggunakan senyawa asimilat yang tersimpan dari bagian tanaman lain seperti biji dan batang, sehingga terjadi penurunan bobot kering biji dan batang.

Pengaruh asam askorbat menunjukkan bahwa vitamin ini mungkin meningkatkan pertumbuhantanaman. Azzedine et al. (2011) mengatakan bahwa penerapan vitamin $\mathrm{C}$ (asam askorbat)efektif untuk mengurangi dampak buruk dari stres garampada pertumbuhan tanaman kedelai karena meningkatan akumulasi prolin didaerahdaun. Peran asam askorbat dalam mengurangi efek 
berbahaya dari stres air terhadap hasil mungkin disebabkan peningkatan konduktansi stomata dan bersih Kegiatan CO2-fiksasi fotosintesis di bawah tekanan air dan juga untuk perannya sebagai antioksidan, kofaktor untuk enzim yang terlibat dalam fotosintesis dan hormon biosintesis.

\section{SIMPULAN}

Perlakuan cekaman kekeringan berpengaruh tidak nyata terhadap seluruh parameter amatan.Perlakuan pemberian antioksidan berpengaruh tidak nyata terhadap seluruh parameter amatan.Perlakuan interaksi cekaman kekeringan dan pemberian antioksidan berpengaruh nyata terhadap tinggi tanaman pada 4 MST dan bobot kering biji.

\section{DAFTAR PUSTAKA}

Adimihardja, A., I. Juarsah dan U. Kurnia. 2000. Pengaruh Penggunaan Berbagai Jenis Takaran Pupuk Kandang Terhadap Produktifitasa Tanah Ultisol Terdegradasi di Desa Batin, Jambi. hlm. 303-319 dalam Pros. Seminar Nasional Sumber Daya Tanah, Iklim dan Pupuk. Buku II. Lido-Bogor, 6-8 Desember 1999. Pusat Penelitian Tanah dan Agroklimat, Bogor.

Ardiansyah. M. 2013. Respons Pertumbuhan dan Produksi Kedelai Hasil Seleksi Terhadap Pemberian Asam Askorbat dan Inokulasi Fungi Mikoriza Arbuskular di Tanah Salin. Universitas Sumatera Utara. Medan.

Arora, A., R.K. Sairam and G.C. Srivastava. 2002. Oxidative Stress And Antioxidative System In Plants. Current Science. 82(10):1227-1238.

Azzedine, F., Gherroucha, H. and Baka, M. 2011. Improvement of salt tolerance in durum wheat by ascorbic acid application. J. Stress Physiol. Biochem.

Dhaubhadel, S. 2003. Isoflavonoid Biosynthesis and Accmulation in
Developing Soybean Seeds. Plant Mol. Biol. 53 (6) : 733-743.

Frederick, J., C. Camp and P. Bauer. 2001. Drought-stress effects on branch and mainstem seed yield and yield components of determinate soybean. Crop Sci 41, 759-763.

Hamayun, M., S.A. Khan, Z.K. Shinwari, A.L. Khan, N. Ahmeed and IJ.Lee. 2010. Effect of polyethylene glycol induced drought stress on physiohormonal attributes of soybean. Pak. J. Bot. 42(2):977-986.

Hendriyani, I. S dan N. Setiari. 2009. Kandungan Klorofil dan Pertumbuhan Kacang Panjang(Vigna sinensis) pada Tingkat Penyediaan Air yang Berbeda. J. Sains \& Mat. 17(3): 145-150.

Hess. J. L. 1993. Vitamin E. a-tocopherol. In: R. G. Alscher and J. L. Hess (eds.) antioxidants in higer plants. pp 111134. CRC Press. Inc. Boca Rarton. Florida.

Lestario, L. N., S. Sugiarto dan K. H. Timotius. 2008. Aktifitas Antioksidan dan Kadar Fenolik Total dari Ganggang Merah (Gracilaria verrucosa L.). Teknol dan Industri pangan, 19 (2); 131-138.

Mursito. D., 2003. heritabilitas dan sidik lintas karakter fenotipik beberapa galur kedelai (Glycine $\max$ (L) Merrill). Fakultas Pertanian, Universitas Sebelas Maret. Surakarta.

Ramadhani, E. 2009. Respons Pertumbuhan dan Produksi Kedelai (Glycine max (L.) Merril.) terhadap Perbedaan Waktu Tanam dan Inokulasi Rhizobium. Universitas Sumatera Utara. Medan.

Purwanto dan Agustono, P. 2010. Kajian Fisiologi Tanaman Kedelai pada Berbagai Kepadatan Gulma Teki dalam Kondisi Cekaman Kekeringan. Jurnal Agroland. 17(2):85-90.

Sharifa dan Muriefah, A. 2015. Effects of Paclubutrazol on Growth and Physiological Attributes of Soybean (Glycine max) Plants Grown Under 
Water Stress Contributions. Int. J. Adv. Res. Biol. Sci. 2(7): (2015): 8193.

Steel, R.G.D dan J.H. Torrie. 1989. Prinsip dan Prosedur Statistika. Diterjemahkan Oleh Bambang Sumantri. Gramedia Pustaka. Jakarta. 